\title{
BENIGN OSTEOPETROSIS
}

\author{
Selçuk YALÇIN \\ Harun YENÍCE \\ Ziya GÜNAL \\ Ümit BAYOL
}

\section{SUMMARY}

A case, referred for the evaluation of anemia, presented with fractures due to trivial trauma and hepatosplenomegally. X-rays showed typical features of osteopetrosis. The diagnosis was confirmed biochemicaly and biopsy of bone. As there is no spesific treatment for benign osteopetrosis, the patient was advised to avoid trauma.

(Keywords: Osteopetrosis, Bone)

\section{ÖZET}

Kliniğimize anemi tetkiki için gönderilen bir olguda küçük travmalarla kırık öyküsü vardı. Fizik muayenede hepatosplenomegali saptandı. Kemik grafilerinde tipik osteopetrozis bulgularına rastlandı. Tanı biyokimyasal tetkikler ve kemik biyopsisi ile doğrulandı. Benign osteopetrozisin spesifik bir tedavisi olmadığından hastaya travmalardan korunması önerilmisstir. (Anahtar Kelimeler: Osteopetrosis, Kemik) 
Osteopetrozis nadir görülen, osteoklastın bozulmuş fonksiyonlarından dolayı normal kemik rezorbsiyonunda azalma, genel kemik kitlesinde artış ile karakterize kalıtsal bir hastaliktır. Normal hematopoezi bozar ve kemiksel delikleri daraltır. Illk kez AlbersSchönberg tarafından tanımlanmıştır. Hastalığın üç formu vardır:

1. Otozomal resesif tip I: Çocukluk çağında görülür, gelişme geriliği, hidrosefali, hepatosplenomegali, sağırlık ve körlük görülebilir. Hasta yaşamının ilk iki yılı içinde kemik iliği yetersizliğinden ölür (1).

2. Otozomal resesif tip II: Çocukluk çağında görülen ve tip I' e göre daha nadir olan bu tipte osteopetrozisin diğer bulgularına ek olarak serebral kalsifikasyon (mermer beyin hastalığ1), renal tübüler asidoz eşlik eder. Bu hastalıkta osteoklasttaki karbonik anhidraz II enzimi eksiktir. Bu enzim asit ortam yaratarak osteoklastın normal aktivasyonunu sağlar. Bu tipte kemik iliği yetersizliği görülmez ve renal tübüler asidoz yaşamı kısıtlar (2).

3. Otozomal dominant tip: Eriskinlerde görülen ve benign seyreden tiptir. Olguların yarısında belirti vermez, geriye kalan olgularda kemiklerde kırılganlık artışı veya genellikle mandibulayı tutan osteomiyelit görülür. Kemik iliği yetersizliği görülmez fakat kranyal sinir basısı olabilir (2).

Osteopetrozis genellikle uzun kemiklerin metafizinde remodeling bozukluğu sonucu Erlenmayer deformitesine neden olmaktadir (2). Kemik yoğunluğunun artmasına karşın kemikler daha frajildir. Bu nedenle mermer kemik hastalığ1 yerine tebeşir kemik hastalığı deyimi önerilmektedir (2). Kırılan kemiğin iyileşmesinde herhangibir bozukluk yoktur. Direkt radyografide korteks, trabeküla, epifiz plağı ve medulla ayırtedilememektedir.

Olguyu sunmaktaki amacımız, hastalığın nadir olması ve karşımıza anemi ve hepatosplenomegali ile çıkabilmesidir.

\section{OLGU}

Manisa SSK' dan sevkle gelen 26 yaşında erkek hasta 18.1.1991 tarihinde 988 karantina no. ile servisimize yatırıldı. Karında şişlik, sol hipokondrium ağrısı olan olgunun son 10 yıl içinde değişik zamanlarda sağ femur, sağ radius ve ulna ve sol üçüncü metakarp kemiklerinde küçük darbelerle kırılma öyküsü vardı. Fizik muayenede hepatosplenomegali ve sol hipokondriumda duyarlılık dişında patoloji saptanmadi. Lökosit $5900 / \mathrm{mm} 3$, eritrosit $3820000 / \mathrm{mm} 3$, $\mathrm{Hb} 10.1 \mathrm{gr} / \mathrm{dL}$, Hct \% 32.5, MCV $85.2 \mathrm{fl}$, trombosit $220000 / \mathrm{mm} 3$, periferik yaymada anizositoz, poikilositoz, göz yaşı damlası hücreleri ve anizokromi bulundu. Lökosit formülü ve trombositler normal, retikülosit $\% 0.5$ idi. Sedimantasyon, kan șekeri, üre, transaminazlar, bilirubinler, alkalen fosfataz, kalsiyum ve inorganik fosfor normal, LDH $772 \mathrm{U} / \mathrm{L}$ (üst sinir $425 \mathrm{U} / \mathrm{L}$ ) bulundu. Üst batın ultrasonografisinde diffüz hepatosplenomegali, el grafilerinde metakarp ve karpal kemiklerde yer yer hiperdens alanlar (kemik içinde kemik görünümleri), önkol grafisinde ulna ve radiusta korteks-medulla ayrımının ortadan kalktığı, kranyum grafisinde tüm kranyum baziste mastoidleri de içine alan skleroze alanlar, maksiller ve frontal sinüslerde dens bir şekilde kapalılık, vertebra grafisinde sandviç vertebra (Rugger Jersey görünümü) saptandı. Kemik iliği aspire edilemedi. Ortopedí kliniğimizde sağ tibiadan alınan biyopside trabeküler alanda kemik iliği aralığının ileri derecede daraltan düzensiz, değişik yaşta hasır örgüsü tarzında kemik formasyonu ile osteoklastik aktivitenin hemen hiç olmadığı saptand1 (393/91 SSK Tepecik Hast. Pat. Lab.). Nörolojik muayenede bilateral optik atrofi saptandı (Uz. Dr. A. İhsan Evinç). Benign osteopetroziste genel olarak herhangi bir tedavi önerilmediği için biz de olgumuza herhangi bir tedavi uygulamadik. 5.2.1991 tarihinde, travmalardan korunması ve kontrollere gelmesi önerilerek çıkarıldı. 


\section{TARTIŞMA}

Hastamizda osteopetrozisin tipik radyolojik, patolojik ve klinik bulgulari vardı. Ayırıcı tanıda Paget hastalığının diffüz osteoskleroz ile seyreden tipinden, Van Buchem hastalığından ve florozisten serum alkalen fosfataz düzeyinin olgumuzda normal oluşu ile ayrildı. Agnojenik miyeloid metaplazide osteoskleroz proksimal kemiklerde sinurlidir, Hodgkin ve multipl miyelomda ise nadiren görülen osteosklerotik lezyonlar çok sınırlı bir alanda görüldüğünden bu özellikleriyle osteopetrozisten ayrıldı. Ayrıca bu hastalıkların tipik klinik özelliklerine olgumuzda rastlanmadi.

Kalıtsal bir hastalık olması nedeniyle olgunun ailesi osteopetrozis yönünden araştırılmak istendiyse de mümkün olmamıştır.

Hayvanlar ve insanlar üzerinde yapılan çalışmalarda malign osteopetrozis olgularında kemik iliği ve dalak hücreleri transplantasyonu ile olumlu sonuçlarin alınmasina karşın benign osteopetroziste herhangi bir tedavi önerilmemektedir. Benign osteopetroziste kemik iliği yetersizliği görülmemektedir. Olgumuzdaki anemi de hafif düzeydeydi, lökosit ve trombosit düzeyleri normaldi. Bu durum gözönüne alınarak bu yönden de herhangi bir tedavi önerilmedi.

Sonuç olarak benign osteopetroziste görülebilen hematolojik ve nörolojik bozukluklar prognozu etkileyecek düzeyde değildir ve bir tedavi gerektirmemektedir. Ancak kemiklerin travmalara karşı aşırı hassasiyeti nedeniyle hastalar bu konuda uyarilmalıdir.

\section{KAYNAKLAR}

1. Strewler GJ. Disorders of Increased Bone Density. In: Wyngarden JB, Smith LH. Cecil Textbook of Medicine. Philadelphia: WB Saunders Company; 1988: 1518-9.

2. Mundy GR. Osteopetrosis. In: Stein JH. Internal Medicine. Boston: Little, Brown and Company; 1990: 2364-6.

3. Rosenthall L. Benign osteopetrosis. Clin Nucl Med. 1990; 15: 412-4.
4. Coccia PF. Succesful bone narrow transplantatiton fon infantile malignant osteopetrosis. $N$ Engl J Med. 1980; 300: 701.

5. Walker DG. Bone resorption restored in osteopetrotic mice by transplants of normal bone narrow and spleen cells. Science. 1975; 190: 784.

6. Cotran RS, Kumar V, Robbins SL. Pathologic Basis of Disease. Philadelphia: WB Saunders Company; 1989: 1318-9.

7. Rosai J. Bone and Joints. In: Stamathis G. Ackerman's Surgical Pathology. Washington: The CV Mosby Company; 1989:1470. 